\title{
ANTISCHISTOSOMAL ACTIVITY OF ACRIDANONE- HYDRAZONES IN CEBUS MONKEYS EXPERIMENTALLY INFECTED WITH THE SJ STRAIN OF SCHISTOSOMA MANSONI
}

\author{
Paulo Marcos Zech Coelho, Leógenes Horácio Pereira ${ }^{\dagger}$ and \\ Rômulo Teixeira de Mello
}

\begin{abstract}
In this study, four compounds were utilized at the dose of $12.5 \mathrm{mg} / \mathrm{kg}$ body weight, p.o., to treat Cebus monkeys experimentally infected with about 200 cercariae of Schistosoma mansoni (SJ strain), via transcutaneous route. The oograms performed with rectal snips, as well as stool examinations carried out periodically, showed no viable eggs of the parasite, from day 29 to 226 post-treatment. The perfusion undertaken after killing the animals showed absence of worms in the treated monkeys, whereas 83 worms were recovered from the control, thus corroborating the results obtained by means of oograms and coproscopy. These results confirm the efficacy of 9-acridanonebydrazones previously tested against the LE strain of S. mansoni. The low curative dose and apparent absence of toxicity render these drugs an important therapeutic reserve, taking into consideration the reports on the resistance of $\mathrm{S}$. mansoni to the modern drugs oxamniquine and praziquantel.
\end{abstract}

Key-words: Schistosoma mansoni. Cebus monkeys. Acridanone-bydrazone

Although much effort has been directed toward the improvement of the chemotherapy for schistosomiasis mansoni, and despite the large progress obtained in this field, curative treatment of this disease with the already known standard antischistosomal compounds presents some difficulties. The high price of drugs, drug side effects, cases of drug resistance, among other problems, point toward the continuous search for new active substances.

Coelho and Pereira showed a promising activity of 9-acridanone-hydrazone compounds in Cebus monkeys experimentally infected with the LE strain of Schistosoma mansoni.

However, a question arises whenever new promising compounds against schistosomiasis appear. Are they effective against all human

Departamentos de Parasitologia, Instituto de Ciências Biológicas, e de Análises Clínicas e Toxicológicas, Faculdade de Farmácia, Universidade Federal de Minas Gerais, Belo Horizonte, $M G$.

This study was supported in part by CNPq, FAPEMIG, PRPq/UFMG, Brazil, and by WHO, Switzerland.

' Deceased 6 February, 1994

Endereço para correspondência: Prof. Paulo Marcos Zech Coelho, Depto de Parasitologia. ICB/UFMG/Caixa Postal 486, 30161-970 Belo Horizonte, MG.

Recebido para publicação em 24/08/94. schistosomiasis, and even if active against a strain of a specific species (S. mansoni, for instance), can their effectiveness be extended to other strains? It is well known that $S$. mansoni, mainly in some countries of Africa, presents different susceptibilities to chemotherapy with oxamniquine, via oral route. Thus, in Brazil and West Africa, $15 \mathrm{mg} / \mathrm{kg}$ body weight is the dosage commonly used, whereas in East Africa the effective dose ranges from 30 to $45 \mathrm{mg} / \mathrm{kg}$, and in Egypt doses of up to $60 \mathrm{mg} / \mathrm{kg}$ given over three days are required ${ }^{16}$. On the other hand, the resistance against oxamniquine by $S$. mansoni has been detected in Brazilian patients ${ }^{16}$. Cioli et $a^{3}$ clearly showed that this resistance was controlled by a single autosomal recessive gene.

In Brazil, three species of Biompbalaria mollusks are responsible for the natural transmission of schistosomiasis mansoni, and these species are predominant as vectors in different areas. Thus, the adaptation between some strains of the parasite and the geographical strains of snails ${ }^{2} 1011$ has been demonstrated, as well as the variation in the pathogenicity degree related to strains of $S$. mansoni has been proved ${ }^{513}$.

The purpose of the present work, using the Cebus monkey model, is to verify whether the 
Coelho PMZ, Pereira LH, Mello RT. Antischistosomal activity of acridanone-bydrazones in Cebus monkeys experimentally infected with the SI strain of Schistosoma mansoni. Revista da Sociedade Brasileira de Medicina Tropical 28:179-183, jul-set, 1995.

SJ strain of S. mansoni (isolated in the State of São Paulo, in an area where Biompbalaria tenagopbila is the snail vector) presents the same susceptibility to the acridanonehydrazones utilized against the LE strain of the parasite (isolated in the State of Minas Gerais, in an area where Biomphalaria glabrata is the snail vector), using the Cebus monkey model too.

\section{MATERIAL AND METHODS}

Capuchin monkeys (Cebus sp), adults of both sexes, were maintained in individual cages in the animal house. The monkeys were fed on daily with bred soaked in milk, fruit, and standard pellet food. They were infected with about 200 cercariae of $S$. mansoni (SJ strain), transcutaneously. The life cycle of the trematode was maintained at the laboratory through hamster - Biomphalaria tenagopbila hamster passages. Acridanone-hydrazone drugs were given after the mature infection had been stablished. The monkeys that were found to be positive (presenting large numbers of schistosome eggs in the stools and in rectal snips) were selected for the experiments. The compounds Ro-15.5458/000, Ro-15.8843/000, Ro-15.9268/000 and Ro-16.2308/000 (Figure 1) were administered at the dosage of $12.5 \mathrm{mg} / \mathrm{kg}$ body weight, by oral route, single dose. The infected monkey E-2 was kept as control. The quantitative oogram of rectal snips, stool examination ${ }^{4}$, and perfusion of portal system for worm recovery 12 were used as criteria for determination of parasitological cure.

\section{RESULTS}

It must be emphasized that the coproscopies performed confirmed the oogram in rectal snips in all cases.

The drug effects against the SJ strain of $S$. mansoni are summarized in Table 1 . The stool examination and perfusion of portal system of the monkeys confirmed the findings obtained with the rectal snips. So, when all the treated monkeys were examined ( 26 examinations per monkey) no eggs could be detected in stool examinations. On the other hand, the presence of viable eggs was detected in all the stool examinations of the control monkey. No worms could be detected through perfusion into the treated monkeys, whereas 83 worms (24 females and 59 males) were recovered from the control monkey (E-2).

\section{DISCUSSION}

Some 9-acridanone-hydrazones have been proved very effective in the preclinical treatment for schistosomiasis, when nonhuman

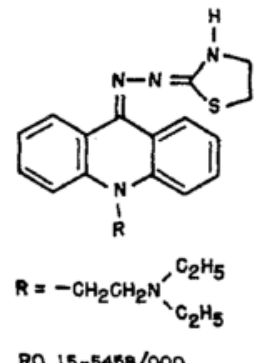

RO $15-5458 / 000$

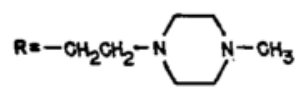

RO $15-9268 / 0000$

WATER INSOLUBLE

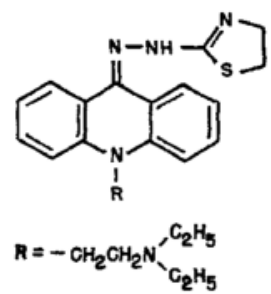

RO 15-8728/002 I:2 HGI

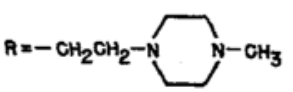

RO 16-9097/0OI 2:5 HCI

WATER SOLUBLE 
Coelbo PMZ, Pereira LH, Mello RT. Antiscbistosomal activity of acridanone-bydrazones in Cebus monkeys experimentally infected with the SJ strain of Schistosoma mansoni. Revista da Sociedade Brasileira de Medicina Tropical 28:179-183, jul-set, 1995. Table 1 - Chemotberapy with 9-Acridanone-bydrazone compounds in Cebus monkeys experimentally infected with the
SJ strain of Schistosoma mansoni.

\begin{tabular}{|c|c|c|c|c|c|c|c|c|}
\hline \multirow[t]{2}{*}{ Monkeys } & \multirow{2}{*}{$\begin{array}{l}\text { Days before (-) } \\
\text { or after }(+) \\
\text { treatment }\end{array}$} & \multicolumn{5}{|c|}{ Oogram (egg stages) } & \multirow[t]{2}{*}{$\begin{array}{l}\text { Dead } \\
\text { eggs }\end{array}$} & \multirow{2}{*}{$\begin{array}{l}\text { Number of viable } \\
\text { eggs per gram of } \\
\text { rectal tissue }\end{array}$} \\
\hline & & $1 \mathrm{st}$ & 2nd & $3 \mathrm{rd}$ & $\frac{0}{4 t h}$ & Mature & & \\
\hline$\overline{\mathrm{E}-2}$ & -8 & 8 & 5 & 2 & 1 & 22 & 24 & 1151 \\
\hline \multirow[t]{16}{*}{ (Control) } & -1 & 4 & 1 & 2 & 0 & 8 & 5 & 325 \\
\hline & +14 & 149 & 54 & 47 & 41 & 96 & 55 & 8096 \\
\hline & +29 & 37 & 28 & 70 & 51 & 265 & 29 & 13072 \\
\hline & +44 & 80 & 12 & 41 & 120 & 184 & 30 & 9296 \\
\hline & +58 & 32 & 16 & 47 & 125 & 175 & 70 & 7900 \\
\hline & +71 & 28 & 9 & 27 & 34 & 40 & 60 & 4313 \\
\hline & +85 & 26 & 16 & 36 & 15 & 144 & 46 & 9480 \\
\hline & +97 & 29 & 50 & 101 & 64 & 148 & 74 & 8000 \\
\hline & +112 & 1 & 11 & 10 & 24 & 84 & 48 & 5417 \\
\hline & +128 & 32 & 1 & 5 & 36 & 121 & 17 & 7222 \\
\hline & +142 & 19 & 25 & 21 & 49 & 142 & 101 & 10667 \\
\hline & +152 & 38 & 15 & 91 & 179 & 311 & 93 & 14089 \\
\hline & +167 & 52 & 3 & 65 & 189 & 229 & 41 & 19656 \\
\hline & +196 & 13 & 15 & 90 & 42 & 220 & 44 & 8750 \\
\hline & +211 & 102 & 70 & 128 & 167 & 389 & 65 & 25206 \\
\hline & +226 & 44 & 23 & 58 & 116 & 114 & 23 & 10350 \\
\hline$\cdot$ E-3 & -8 & 1 & 2 & 8 & 1 & 57 & 3 & 1169 \\
\hline Treated with & -1 & 0 & 1 & 5 & 8 & 27 & 13 & 719 \\
\hline Ro-15.5458/000 & +14 & 0 & 0 & 0 & 0 & 4 & 3 & 94 \\
\hline \multirow[t]{3}{*}{$12.5 \mathrm{mg} / \mathrm{kg}$, p.o } & +29 & 0 & 0 & 0 & 0 & 0 & 2 & 0 \\
\hline & +44 & 0 & 0 & 0 & 0 & 0 & 0 & 0 \\
\hline & +58 & 0 & 0 & 0 & 0 & 0 & 0 & 0 \\
\hline${ }^{*} \mathrm{E}-4$ & -8 & 5 & 7 & 1 & 0 & 72 & 18 & 2125 \\
\hline Treated with & -1 & 3 & 2 & 9 & 8 & 59 & 23 & 1528 \\
\hline Ro- $15.8843 / 000$ & +14 & 0 & 0 & 0 & 0 & 2 & 7 & 52 \\
\hline \multirow[t]{3}{*}{$12.5 \mathrm{mg} / \mathrm{kg}$, p.o. } & +29 & 0 & 0 & 0 & 0 & 0 & 1 & 0 \\
\hline & +44 & 0 & 0 & 0 & 0 & 0 & 0 & 0 \\
\hline & +58 & 0 & 0 & 0 & 0 & 0 & 0 & 0 \\
\hline - E-5 & -8 & 6 & 13 & 1 & 9 & 62 & 10 & 1468 \\
\hline Treated with & -1 & 5 & 4 & 5 & 10 & 58 & 38 & 1344 \\
\hline Ro-15.9268/000 & +14 & 0 & 0 & 0 & 0 & 1 & 10 & 21 \\
\hline \multirow[t]{3}{*}{$12.5 \mathrm{mg} / \mathrm{kg}$, p.o. } & +29 & 0 & 0 & 0 & 0 & 0 & 3 & 0 \\
\hline & +44 & 0 & & 0 & 0 & 0 & 0 & 0 \\
\hline & +58 & 0 & . & 0 & 0 & 0 & 0 & 0 \\
\hline • E-6 & -8 & 2 & 10 & 35 & 18 & 67 & 18 & 1941 \\
\hline Treated with & -1 & 16 & 59 & 57 & 30 & 186 & 58 & 6327 \\
\hline Ro-16.2308/000 & +14 & 0 & 0 & 0 & 0 & 4 & 19 & 72 \\
\hline \multirow[t]{3}{*}{$12.5 \mathrm{mg} / \mathrm{kg}$, p.o. } & +29 & 0 & 0 & 0 & 0 & 0 & 12 & 0 \\
\hline & +44 & 0 & 0 & 0 & 0 & 0 & 0 & 0 \\
\hline & +58 & 0 & 0 & 0 & 0 & 0 & 0 & 0 \\
\hline
\end{tabular}

$+167,+196,+211$ and +226 , did not detect viable eggs.

primate models, as baboons ${ }^{14}$ and Cebus monkeys ${ }^{4}$, were used. Very good results have been reported by Coelho and Pereira ${ }^{4}$ using Cebus monkeys infected with the LE strain of $S$. mansoni, and treated with some acridanonehydrazones that showed curative activity at doses as low as $25 \mathrm{mg}$, sometimes $12.5 \mathrm{mg}$, per os, single administration. These authors showed that the results obtained thiough periodical rectal biopsies and stool examinations carried out prior and up to six months after treatment were really curative. In some cases, some treated simians (negative for coproscopies and rectal biopsies) were sacrificed at that time, and few or no worms could be found after the portal system perfusion, thus showing that the laboratory findings were not due to chemical sterilization of the worms but, in fact, were associated with the consequent death of the parasites. In that 
Coelho PMZ, Pereira LH, Mello RT. Antischistosomal activity of acridanone-hydrazones in Cebus monkeys experimentally infected with the SJ strain of Schistosoma mansoni. Revista da Sociedade Brasileira de Medicina Tropical 28:179-183, jul-set, 1995.

occasion, it was verified that the curative doses, besides being quite low, and singly orally administered, did not show visible side effects on the primates.

In the same work, it has been observed a marked activity of all the compounds studied against the SJ strain of $S$. mansoni, at a lower dose $(12.5 \mathrm{mg} / \mathrm{kg})$, thus confirming the results obtained by Coelho and Pereira ${ }^{4}$ with the LE strain. These results lead the authors to think on the possibility of the same compounds being successful in a lower curative dose (less than $12.5 \mathrm{mg} / \mathrm{kg}$ body weight in Cebus monkeys). It is well known that many schistosomicides in the monkey require near five times more dosing than that used for man. Thus it seems that doses lower than $3 \mathrm{mg} / \mathrm{kg}$ body weight could possibly be used for man, although it must be proved whether the toxicity of these compounds does not prevent their use in humans.

The report on drug resistance related to the use of oxamniquine, the most utilized drug in the treatment for schistosomiasis in Brazil ${ }^{17}$, widen the possibility of considering the drugs here studied as an important reserve supply to be used, perhaps, in the near future.

\section{RESUMO}

No presente trabalho, quatro compostos foram utilizados na dose de $12,5 \mathrm{mg} / \mathrm{kg}$ de peso, por via oral, em macacos infectados transcutaneamente com cerca de 200 cercárias de Schistosoma mansoni. Os oogramas realizados com fragmentos de mucosa retal e os exames de fezes realizados, periodicamente, demonstraram a ausência de ovos viáneis do parasito a partir do $29^{\circ}$ até o $226^{\circ}$ dia pós-tratamento. A perfusão, após sacrificio dos animais tratados, não detectou vermes, enquanto que do macaco controle 83 vermes foram recuperados, confirmando assim os resultados dos oogramas e da coproscopia. Estes resultados confirmam a eficácia das 9-acridanonasbydrazonas já observada anteriormente contra a cepa $L E$ de S. mansoni. A baixa dosagem curativa e aparente ausência de toxicidade colocam estas drogas como uma reserva terapêutica importante, tendo em vista o relato de resistência do S. mansoni as drogas modernas oxamniquina e praziquantel.

Palauras-chaves: Schistosoma mansoni. Macacos Cebus. Acridanona-bidrazonas.

\section{ACKNOWLEDGEMENTS}

To Dr. H.R. Stohler (F. Hoffmann-La Roche \& Co. Ltd., Basle, Switzerland) for providing the compounds used in this work, as well as for financial support and advice; Dr. Faiçal Simon and Dr. Adayr Mafuz Saliba (Fundação Parque Zoológico de São Paulo) for the supply of Cebus monkeys; Mrs. Vera de Paula Ribeiro for translating the manuscript; Mr. Adelino Ferreira (in memoriam), Mr. Maurício V. Costa (in memoriam), Mr. Alberto G. Santos and Miss Zenir de Souza for technical assistance.

\section{REFERENCES}

1. Araújo N, Katz N, Dias EP, Souza P. Susceptibility to chemotherapeutic agents of strains of Schistosoma mansoni isolated from treated and untreated patients.The American Journal of Tropical Medicine and Hygiene 29:890-894, 1980.

2. Barbosa FS, Barreto AC. Differences in susceptibility of Brazilian strains of Australorbis glabratus to Schistosoma mansoni. Experimental Parasitology 9: 137-140, 1960.

3. Cioli D, Pica-Mattoccia L, Moroni R. Schistosoma mansoni: hycanthone/oxamniquine resistance is controlled by a single autosomal recessive gene. Experimental Parasitological 75: 425-432, 1992.

4. Coelho PMZ, Pereira LH. Scbistosoma mansoni: Preclinical studies with 9-acridanone-hydrazones in Cebus monkeys experimentally infected. Revista do Instituto de Medicina Tropical de São Paulo 33: 50-57, 1991.

5. Coelho PMZ, Raso P, Mello RT, Toppa NH. Dimensões do granuloma hepático produzido por ovos de duas linhagens geográficas do Schistosoma mansoni, no camundongo. Memórias do Instituto Oswaldo Cruz 84: 213-217, 1989.

6. Dias LCS, Gonçalves ER. Schistosoma mansoni diz não às drogas. Ciência Hoje 14: 22-25, 1992.

7. Dias LCS, Pedro RJ, Deberaldini ER. Use of praziquantel in patients with schistosomiasis mansoni previously treated with oxamniquine and/or hycanthone: resistance of Schistosoma mansoni to schistosomicidal agents. Transactions of the Royal Society of Tropical Medicine and Hygiene 76: 652-659, 1982.

8. Files VS, Cram EB. A study on the comparative susceptibility of snails vector to strains of Schistosoma mansoni. Journal of Parasitology 35:555-560, 1949.

9. Katz N, Pellegrino J, Pompéu-Memória JM. Quantitative oogram method in Cebus monkeys experimentally infected with Schistosoma 
Coelbo PMZ, Pereira LH, Mello RT. Antischistosomal activity of acridanone-bydrazones in Cebus monkeys experimentally infected with the SI strain of Schistosoma mansoni. Revista da Sociedade Brasileira de Medicina Tropical 28:179-183, jul-set, 1995.

mansoni. Journal of Parasitology 52:917-919, 1966.

10. Newton WL. The inheritance of susceptibility to infection with Scbistosoma mansoni in Australorbis glabratus. Experimental Parasitology 2: 242-257, 1953.

11. Paraense WL, Correa R. Variation in susceptibility of populations of Australorbis glabratus to a strain of Schistosoma mansoni. Revista do Instituto de Medicina Tropical de São Paulo 5: 1522, 1963.

12. Pellegrino J, Siqueira AF. Técnica de perfusão para colheita de Schistosoma mansoni em cobaias experimentalmente infestadas. Revista Brasileira de Malariologia 8: 589-597, 1956.

13. Saoud MFA. The infectivity and pathogenicity of geographic strains of Schistosoma mansoni. Transactions of the Royal Society of Tropical Medicine and Hygiene 60:585-600,1966.
14. Sturrock RF, Bain J, Webbe G, Doenhoff MJ, Stohler H. Parasitological evaluation of curative and subcurative doses of 9-Acridanone-hydrazone drugs against Schistosoma mansoni in baboons, and observations in serum levels of anti-egg antibodies detected by ELISA. Transactions of the Royal Society of Tropical Medicine and Hygiene 81: 188-192, 1987.

15. Warren KS. Comparison of Puerto Rican, Brazilian, Egyptian and Tanzanian strains of Schistosoma mansoni in mice: penetration of cercariae, maturation on schistosomes and production of liver disease. Transactions of the Royal Society of Tropical Medicine and Hygiene 61: 795-802, 1967.

16. World Health Organization. The role of chemotherapy in schistosomiasis control. WHO/Schisto/83.70, Revue.1. World Health Organization 1:24, 1983. 